\title{
CLONING AND CHARACTERIZATION OF THE GENE ENCODING THE PEPF ENDOPEPTIDASE FROM THE AQUATIC BACTERIUM CAULOBACTER CRESCENTUS
}

\author{
Vânia S. Braz; Elza A.S. Lang; Marilis V. Marques*
}

Departamento de Microbiologia, Instituto de Ciências Biomédicas, Universidade de São Paulo, São Paulo, SP, Brasil

Submitted: December 05, 2001; Returned to authors for corrections: January 09, 2002; Approved: February 25, 2002

\begin{abstract}
The metallopeptidases have a very important role in bacteria, being involved in several processes that rely on protein turnover, such as nutrition, degradation of signal peptides, protein localization and virulence. We have cloned and characterized the gene of the metalloendopeptidase PepF from the aquatic bacterium Caulobacter crescentus. The gene upstream of pepF (orfl) encodes a conserved hypothetical protein found in Mycobacterium and Streptomyces. pepF is co-transcribed with the gene downstream (orf3), which encodes a protein that belongs to the $\mathrm{ABC} 1$ protein kinase family, suggesting that these two proteins may share a common function in the cell. The $C$. crescentus PepF protein possesses the conserved HEXGH motif present in zinc binding domains of PepF homologs. Disruption of the $p e p F$ gene by insertion of a vector sequence did not produced any growth defect, but the mutant strain possesses only $30 \%$ of the specific activity of endopeptidases present in the wild type strain. Deletions and point mutations in the regulatory region showed that there are two putative promoter regions, and the operon expression is independent of the transcription regulator CtrA. The results indicate that PepF is not essential for either growth or development of this bacterium using peptides as the sole carbon source, suggesting that other peptidases can be sharing this function.
\end{abstract}

Key words: endopeptidase, M3 family, gene regulation, bacteria

\section{INTRODUCTION}

Bacterial peptidases are involved in several important processes in bacterial cells, such as protein localization, hydrolysis of imported peptides, protein turnover and virulence. The metallopeptidases comprise a large group of proteins and are categorized in several families, according to their sequence similarity and function (22). The zinc-dependent metallopeptidases are found in bacteria, protozoa, fungi, plants and animals, and share a common amino acid motif that comprises the zinc-binding site (11). The PepF peptidases are included into family M3, and this class of peptidases is found in all organisms except for viruses and the archaebacteria.

PepF homologs have been found in both Gram negative and Gram positive bacteria, but the role of this protein in the cell was determined only in Lactococcus lactis, where two pepF genes were found, one encoded in a plasmid and one in the chromosome (16,17). In L. lactis, PepF is involved in the ability of the bacterium to utilize milk casein as a carbon source, where it is responsible for degradation of peptides from 7 to 17 amino acids in size (16). The loss of the plasmid copy of pepF leads to a $75 \%$ reduction in total endopeptidase activity, indicating that this oligopeptidase is responsible for most of this activity in the cell (16).

The aquatic bacterium Caulobacter crescentus presents an obligatory differentiation step in each cell cycle, generating by cell division a motile swarmer cell and a sessile stalked cell $(3,9)$. Its unique developmental program has been extensively studied, several key regulatory genes have been identified, and proteolysis plays an important role in regulating $C$. crescentus

\footnotetext{
* Corresponding author. Mailing address: Departamento de Microbiologia, Instituto de Ciências Biomédicas, Universidade de São Paulo. Av. Prof. Lineu Prestes 1374, 05508-900, São Paulo, SP, Brasil. Phone: (+5511) 3091-7299. FAX: (+5511) 3091-7354. E-mail: mvmarque@usp.br
} 
development (10,25). Despite being a heterotroph, Caulobacter has a preference for growing in very dilute environments, which implies having an efficient way of taking organic matter, and therefore oligopeptidases must have an important role in this bacterium. The recently completed genome sequencing of $C$. crescentus (19) showed 48 genes encoding putative peptidases that belong to different families, but only one was predicted to be from the M3 family, a PepF homolog. In this report, we describe the genetic organization of the locus encoding the only pepF homolog found in the genome from $C$. crescentus and characterize its regulatory regions.

\section{MATERIALS AND METHODS}

\section{Bacterial strains and media}

Caulobacter NA1000 is the wild type, synchronizable strain (7) and the LS2195 strain has a temperature-sensitive allele of the $c t r A$ gene (21). E. coli S17-1 contains the mobilization genes that allow DNA transfer by conjugation to $C$. crescentus (23). Caulobacter strains were grown at $30^{\circ} \mathrm{C}$ in PYE complex media or M2 minimal media (6), as indicated.

\section{Cloning and characterization of the pepF locus}

The first half of the $p e p F$ gene was identified in a clone previously isolated in our laboratory (14). To obtain the complete region containing pepF gene, two partial libraries were constructed in vector pUCBM20 (Boehringer Mannheim) by digestion of the original cosmid clone, one library containing HindIII/PstI fragments and the other containing SacI/BamHI fragments. The first library was screened with radioactive probes corresponding the beginning of pepF. A positive HindIII/Pst I clone of $2.4 \mathrm{~kb}$ was obtained and its DNA sequence was determined after subcloning into M13mp18 (Gibco BRL). The nucleotide sequence of this clone showed it contained the complete pepF coding region, encompassing $1.6 \mathrm{~kb}$, and part of a third ORF (ORF3). A SacI/BamHI clone of $2.3 \mathrm{~kb}$ was isolated, by hybridization with a probe corresponding to the beginning of ORF3. This clone was completely sequenced, showing that ORF3 is $1.2 \mathrm{~kb}$ long and no other ORF could be identified immediately downstream of it, using the GeneMark algorithm (1) (Fig. 1).

\section{RT-PCR}

In order to determine whether the three genes are organized in an operon, RT-PCR reactions using $1 \mu \mathrm{g}$ of total RNA and primers flanking each intergenic region were performed with the SuperScript One-Step RT-PCR kit (Gibco BRL). RT-PCR between orfl and $p e p F$ was performed using the pair of primers RT-1/RT2 (RT-1: 5'-GCGATGGCCTGGAGCTATC-3', RT-2: 5' ACTAGCAGATAGGCCTCCG-3'), and between pepF and orf3 was performed using the pair RT-3/RT-4 (RT-3: 5' GCCGCTTTATGAGCAACTGC-3', RT-4: 5'-GGTTGGCACCG
TAAGACAC-3'). As a negative control for each RT-PCR, the reverse transcriptase was ommited from the reactions.

\section{Mapping of regulatory regions}

In order to define more precisely the regulatory sequences involved in pep expression, different promoter constructions were cloned in front of a reporter lacZ gene (plasmid pRKlacZ290, (8)), and the levels of expression were determined by measuring b-galactosidase activity (15). Site-directed mutagenesis was performed using primer tac3 (5'-GCATAAGACCCTGTTA AGCCTAAG-3') or tac7 (5'-TCCGAAAGCCGGTGTTTA CCCGCGACCTG-3') as described (12). pVB04 was obtained by cloning the $0.37 \mathrm{~kb} H$ indIII/StuI fragment containing part of the orfl gene into vector pRKlacZ290. pVB01 was obtained by PCR using primers tac5 (5'-TCGCGCTCGAGCACCGCTTGA3') and V2 (5'-CAGCACGCCGGGATCCAGCACGCGCGC-3').

\section{Construction and analysis of a pepF/orf3 mutant}

To obtain a null mutant of the pepF gene, a $0.65 \mathrm{~kb}$ SacI/StuI fragment corresponding to the central region of the gene was cloned into plasmid pNPTS138. The recombinant plasmid was introduced by electroporation into $E$. coli S17-1 and the cells were plated in $\mathrm{LB} / \mathrm{Km}$ plates. The plasmid was transferred to Caulobacter strain NA1000 by conjugation (6). To confirm the correct integration of pNPTS138 in the pepF locus, genomic DNA from the transformed clones was purified (5), digested with SacI and transferred to a nylon membrane. The correct integration of the plasmid was confirmed by hybridization with radioactive probes corresponding to either the pNPTS138 plasmid or to the $0.65 \mathrm{~kb} \mathrm{SacI} / \mathrm{StuI}$ fragment. The mutant strain was designated SP2008.

\section{Determination of endopeptidase activity}

Endopeptidase activity was assayed in C. crescentus strains NA1000 and SP2008 grown to midlog phase. Cells were separated from the culture medium by centrifugation for 15 minutes at $7500 \mathrm{x} \mathrm{g}$, and ressuspended in buffer A (50 mM Tris- $\mathrm{HCl} \mathrm{pH} \mathrm{7.0/}$ $20 \mathrm{mM} \mathrm{NaCl}$ ). Cells were broken by sonication (four pulses of 15 seconds in a Branson Sonifier 250), and cell debris was removed by centrifugation for 5 minutes at $12,000 \mathrm{x}$ g. The enzymatic assay of either cell extracts or culture supernatants was carried out as described (20) in a final volume of $1 \mathrm{ml}$ of buffer A, containing or not $0.5 \mathrm{mM}$ DTT, and the quenched fluorogenic peptide substrate QF7 (orto-aminobenzoyl (Abz)Gly-Gly-Phe-Leu-Arg-Arg-Val-(2,4,dinitrophenyl) ethylenediamine (EDDnp). Protein concentration was determined by the Bradford assay (BioRad).

\section{RESULTS AND DISCUSSION}

Sequencing of the pepF gene region showed that it is preceded by a small ORF (ORF1) and that downstream there is 
another ORF $1.2 \mathrm{~kb}$ long (ORF3) which is separated of pepF by only one base pair (Fig. 1). Our results were later confirmed by the complete genome sequencing, where the genes correspond to numbers CC3314 (orfl), CC3313 (pepF) and CC3312 (orf3) in the TIGR database (see http://www.tigr.org).

In order to determine whether the three genes are organized in an operon, RT-PCR reactions using primers flanking each intergenic region were performed. As shown in Figure 2, an amplification product is obtained between $p e p F$ and ORF3, only when the reverse transcriptase is present, while the negative control without this enzyme did not show any amplified band. This result shows that these two genes are transcribed in a single mRNA species. Confirming this result, no promoter activity was observed when the $1.2 \mathrm{~kb} \mathrm{XhoI/StuI} \mathrm{restriction}$ fragment between $p e p F$ and ORF3 was cloned in front of the reporter gene lacZ, indicating that there is no promoter in this

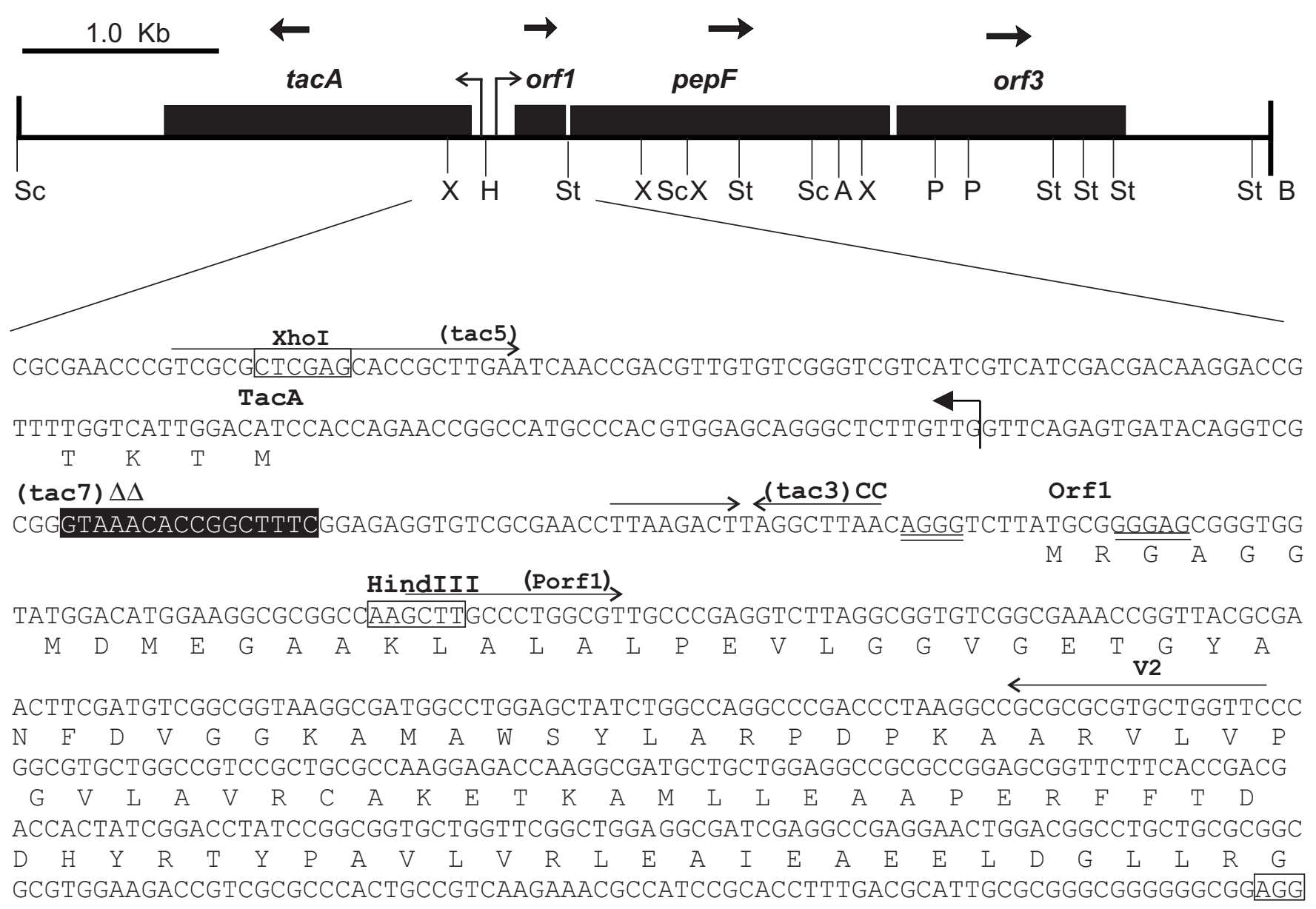

$\begin{array}{llllllllllllllllll}A & W & K & \mathrm{~T} & \mathrm{~V} & \mathrm{~A} & \mathrm{P} & \mathrm{T} & \mathrm{A} & \mathrm{V} & \mathrm{K} & \mathrm{K} & \mathrm{R} & \mathrm{H} & \mathrm{P} & \mathrm{H} & \mathrm{L} & \text { * }\end{array}$

StuI

CCTATCTGCTGATCCATGAACGCGCCC

$$
\begin{array}{lll}
M & N & A \\
\text { PepF }
\end{array}
$$

Figure 1. Structural organization of the region of the $C$. crescentus chromosome containing the pepF gene, and DNA sequence of the region from tacA to $p e p F$. The boxes represent the open reading frames, and arrows indicate the direction of transcription. Restriction sites are indicated as follows: Sc, SacI; X, XhoI; H, HindIII; St, StuI; A, ApaI; P, PstI, and B, BamHI. Deduced amino acids of the corresponding genes are shown below the respective codons. Restriction sites are boxed. Small arrows mark inverted repeats. Nucleotides altered by site-directed mutagenesis are indicated above the sequence (tac 3 and tac 7 ), $\triangle$ indicates deletion of bases. Putative ribosomal binding sites are double underlined. Bent arrow, tacA transcription start site. Single arrows, oligonucleotides used to generate promoter deletions. Consensus sequence for a CtrA-binding site is shaded. 


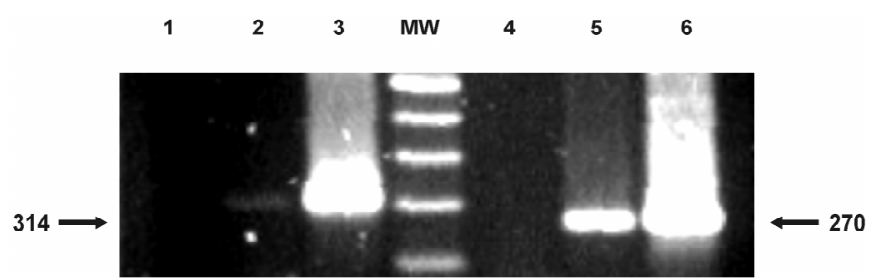

Figure 2. Analysis of the transcripts of the pepF operon. RTPCR reactions were performed using $1 \mu \mathrm{g}$ of total RNA as template with the respective primers, and analyzed on a nondenaturing $6 \%$ polyacrylamide gel. Lanes $1-3$, analysis of transcript between orfl and pepF: Lane 1, PCR reaction with primers RT-1/RT-2 without reverse transcriptase (negative control); lane 2, RT-PCR reaction using primers RT-1/RT-2 (a specific band of $314 \mathrm{bp}$ was produced); lane 3 , PCR reaction with Taq DNA polymerase, primers RT-1/RT-2 and plasmid DNA template (positive control). Lanes 4-6, analysis of transcript between $p e p F$ and orf3: Lane 4, PCR reaction with primers RT3/RT-4 without reverse transcriptase (negative control); lane 5, RT-PCR reaction using primers RT-3/RT-4 (a specific band of 270 bp was produced); lane 6, PCR reaction with Taq DNA polymerase, primers RT-3/RT-4 and plasmid DNA template (positive control).

region (not shown). RT-PCR between ORF1 and pepF (Fig. 2, lane 2) produced a very faint band, although specific, and this result could not be improved after several attempts. The intergenic space between orfl and pepF is small (41 bp); no putative regulatory sequences could be identified in this region; and there is no intrinsic transcription terminator between orfl and $p e p F$. These results altogether indicate that orfl is cotranscribed with pepF and orf3.

The deduced amino acid sequences of the three ORFs were compared to the available databases. ORF1 is similar to hypothetical proteins from Mycobacterium tuberculosis (35\% identity) and Streptomyces coelicolor (39\% of similarity). PepF presents strongest similarity to PepF from Helicobacter pilori (33\% identity) and from Lactococcus lactis (29\% identity) (Fig. 3 ). A domain analysis of PepF showed that it presents a common domain to several other metallopeptidases (PRODOM domain PD005933), sharing with these proteins the zinc-binding region signature (HEXGH) (22), and it also contains a putative transmembrane domain from amino acids 71 to 91 .

ORF3 was annotated as a conserved hypothetical protein in the genome analysis (19), but a further analysis showed that it belongs to the large $\mathrm{ABC} 1$ protein kinase family, which includes representatives both in eukaryotes and prokaryotes (13). ORF3 presents strongest similarity to a hypothetical protein from $S$. coelicolor (29\% identity), to a hypothetical protein from $C$. elegans (28\% identity), to hypothetical protein Rv3197 from $M$. tuberculosis (32\% identity), to a putative $\mathrm{ABC}$ transporter from Methanobacterium thermoautotrophicum (29\% identity) and to several eukaryotic $\mathrm{ABC} 1$ homologs. The $\mathrm{ABC} 1$ family includes several eukaryotic proteins that are essential for the efficient functioning of the mitochondrial $b c l$ complex, as well as the $E$. coli $u b i B$ gene, that is required for ubiquinone biosynthesis (2). The pepF gene disruption in strain SP2008 (see below) could lead to a polar effect in the orf 3 gene, since no promoter activity was detected between these two genes. Caulobacter is an obligatory aerobic prokaryote, therefore any mutations that impair respiration should be deleterious to the cell. Strain SP2008 shows no growth defect that could indicate a loss of respiratory function, which suggests that the role of ORF3 is probably not related to respiratory chain function.

A pepF null mutant was constructed by disrupting the gene with a plasmid encoding a kanamycin resistance marker, the insertion of the plasmid in the pepF locus was confirmed by Southern blotting (not shown). The pepF::pNPTS138 strain (SP2008) showed no growth defects, with a doubling time of 3 $\mathrm{h}$, equivalent to the wild type strain NA1000, and normal swimming behaviour was observed by light microscopy. To assess whether a pepF/orf3 mutation would have an effect on survival under stress conditions, a nutritional stress was induced by allowing the cells to enter stationary phase, and cell viability was determined. SP2008 showed no reduction in viability during the stationary phase when compared to strain NA1000, indicating that PepF and ORF3 are not essential for cell viability during prolonged growth. Strain SP2008 is also able to grow in peptone/yeast extract medium, indicating that PepF activity is not essential for nutrition under these conditions.

Since the $p e p F$ gene encodes a peptide highly similar to metalloendopeptidases of the M3 family, endopeptidase activity of strain SP2008 was assayed towards a peptide that is a substrate for the thimet mammalian oligopeptidases (20). In order to have an indication whether PepF localization is cytoplasmatic or extracellular, endopeptidase activity was determined in the culture supernatants as well as in total cell extracts. Some mammalian metalloendopeptidases that belong to the M3 family are the socalled thimet peptidases, whose activity is dependent on thiol (22). Activity was assayed using a quenched peptide substrate that becomes fluorescent when cleaved by an endopeptidase, in the presence and absence of $0.5 \mathrm{mM}$ DTT. As observed in Table 1, the supernatants of both NA1000 and SP2008 cultures showed a similar specific activity, indicating that a similar set of enzymes are secreted in both cases. The absence of PepF activity in the cell culture medium does not support the hypothesis of the peptidase being secreted, and so it is probably localized in the cytoplasm or associated with the cell membrane. However, endopeptidase activity measured in cell extracts using this substrate, showed a $30 \%$ reduction on specific activity of strain SP2008 when compared to strain NA1000, suggesting that disruption of pepF caused a loss of a significant cellular 


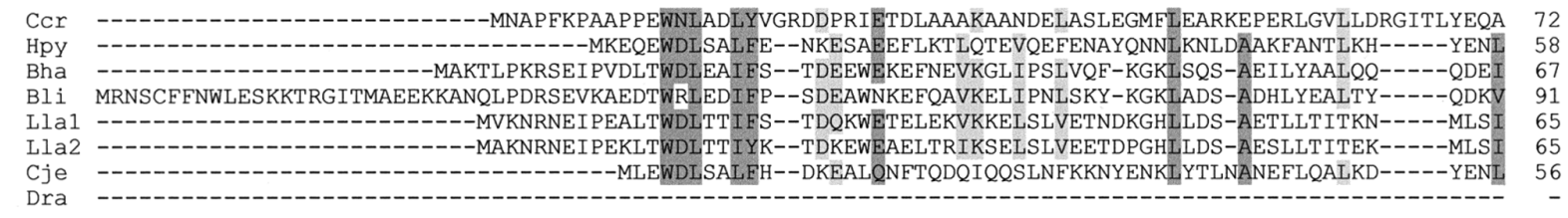

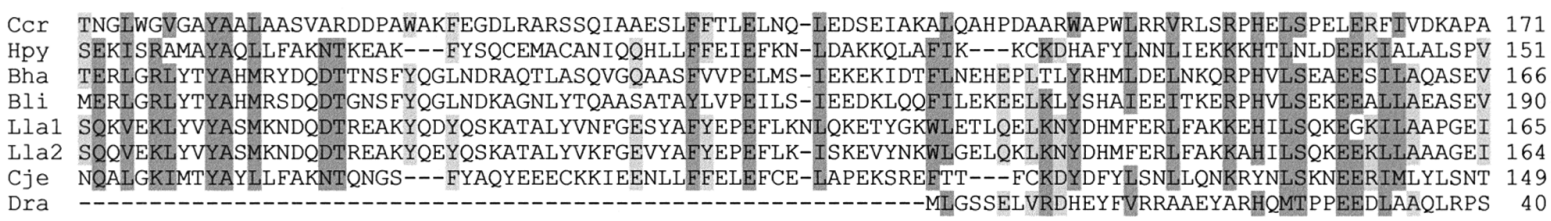

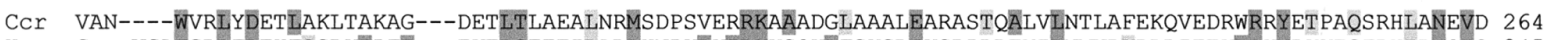
HPY G---VGAFSRLFDEHFSSLKIPFE----EKTLSEEEILALLHNPKRKIRKKSQKAFSKSLEKSRPLLTYILNMVRKDLLIETKLRKYDKKESFRHIDNQIS 245 Bha TSAPSNT EGML NNADMTFPTIVNENGEEVEVTHGRYLQFLESGDRRVRKDAFQAVYSTYEKYKNTEASTTLSSQVKRDLFYANVRKYKSAREAALSRNFIP 266 Bli LGSSSNT ESVLNNADITFPS IKDEDGNEKQITHGNFINFLESENREVRKNAFDAVYKTYGQYKNTMATTLSGTVKKDNFYARVKKYKSAREAALSNNSIP 290 Lla1 FESPSET FEIFDNADVKFPFVKNELGEKIQLTHGNYGSLMESENREVRKAAYEALYSNYEQCQHTYAKTLQTNVKVHNFNAQIRAYDSARQAALMSNFVP 265 Lla2 FESPSET EEIFDNADIKL PMVKNESDEMIQLTHGNYSSLMESKNRGVRKAAYKALYSNYEQYQHTYAKTLQTNVKVHNLNAQIRSYDSARQAALANNFVP 264 Cje G---ANAFSRIFDESMSALKIPFE---GKKLSEEEILSKMYDENRKIRKKAAKKFSKVLQKNSRLLSFI INMIKTERKNISLLRGYENAEISRHISNQIS 243 Dra G---AGGWGKLHGNFTSQLRGEYR---GELLPVTALRALATEPDEAVRRDAFEÄELKVWRESDTVTÄACMNGVKGEEGTLARRRGEAEPLDVSLLNNGID 134

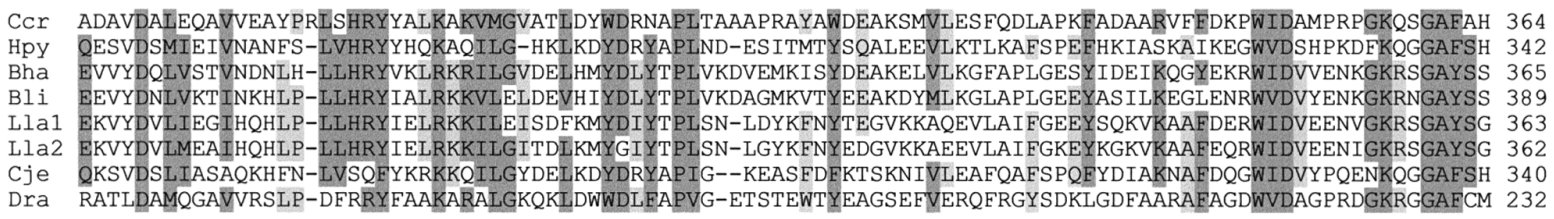
Zn-binding motif
Ccr
HPVTADRHPFVFMNYMGERRDVLTLAHELGHAVHQTLCQ-PLGTLLADTPLTLAETASIFGEGLVFDRLLAEASPE-DRKGLIAGKIEDGLNTVVRQIAËH
Bha
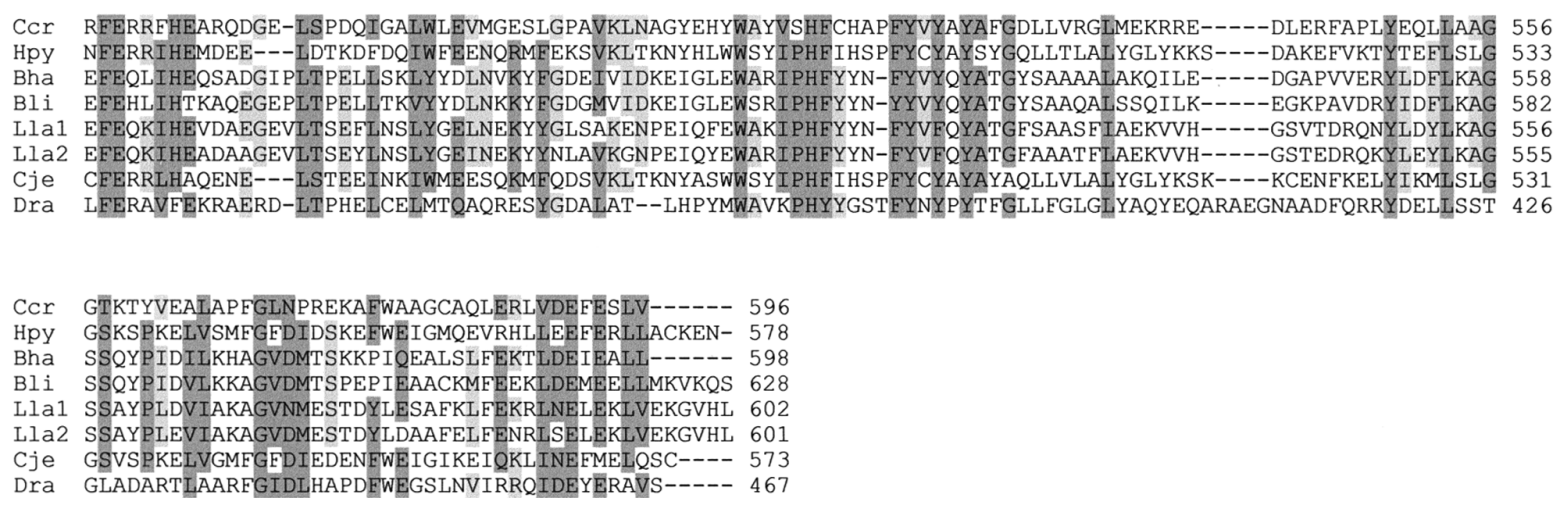

Figure 3. Amino acid sequence alignments of the product of the pepF gene. Alignment was done using the ClustalW program (22), and edited using the GeneDoc program (23). Amino acids are shaded according to degree of conservation. PepF from Caulobacter (Ccr) is compared to putative metallopeptidases from H. pylori (Hpy; B71934), B. halodurans (Bha; BAB06575), B. licheniformis (Bli; T44581), L. lactis chromosomal gene product (Lla1; P94876) and L. lactis plasmid gene product (Lla2; P54124), C. jejuni (Cje; F81313), D. radiodurans (Dra; B75322). The conserved zinc-binding motif is indicated above the sequence. Amino acid numbers are indicated at the right of each sequence. 
Table 1. Assays for endopeptidase activity of the wild type strain NA1000 and the mutant strain SP2008.

\begin{tabular}{lcc}
\hline \multicolumn{1}{c}{ Samples $^{\mathbf{a}}$} & $\begin{array}{c}\text { Specific activity }^{\mathbf{b}} \\
\text { (nmol.min }^{-1} \cdot \boldsymbol{\mu} \mathbf{~ g}^{-\mathbf{1}} \text { ) }\end{array}$ & $\begin{array}{c}\text { Relative } \\
\text { activity }^{\mathbf{c}}\end{array}$ \\
\hline NA1000 extract (+DTT) & $548 \pm 14$ & 1.0 \\
NA1000 extract (-DTT) & $949 \pm 47$ & 1.73 \\
SP2008 extract (+DTT) & $368 \pm 13$ & 0.67 \\
SP2008 extract (-DTT) & $443 \pm 17$ & 0.80 \\
NA1000 Sn (+DTT) & $192 \pm 31$ & 1.0 \\
NA1000 Sn (-DTT) & $361 \pm 13$ & 1.88 \\
SP2008 Sn (+DTT) & $262 \pm 22$ & 1.36 \\
SP2008 Sn (-DTT) & $372 \pm 57$ & 1.93 \\
\hline
\end{tabular}

${ }^{a}$ Activity was measured for cell extracts and for the cultures supernatants $(\mathrm{Sn}){ }^{\mathrm{b}}{ }^{\mathrm{b}}$ The numbers represent the average followed by the standard deviation; ${ }^{\mathrm{c}}$ Activities are shown relative to the specific activity of NA1000 cell extract in the upper part of the Table and to the specific activity of NA1000 supernatant in the lower part

endopeptidase activity in the mutant. This result also indicates that there are other peptidases in the cell that are able to cleave this substrate, which agrees with the presence of so many genes encoding peptidases in the genome (19). Forty-eight gene products were annotated as putative peptidases, out of which nine are from the M20/25/40 families, seven from the M23/27 families, four from the M16 family and one representative of each of the M1, M3, M13, M22 and M24 families.

An increase in activity was observed when the assays were carried out in the absence of DTT in all cases, indicating that even if there is a thiol-dependent endopeptidase in Caulobacter, its activation is not very pronounced, and some of the enzymes are in fact inhibited by thiol. Our results show that $C$. crescentus PepF hydrolyzes the peptide of 7 residues that is a substrate for the mammalian thimet oligopeptidase (4). The L. lactis PepF is also capable of hydrolyzing peptides very similar to this, containing 7 to 17 amino acids, with a cleavage site preference after a Phe residue (16). The substrate specificity of $C$. crescentus PepF has not been determined, but since it is similar to the L. lactis enzyme, some of its catalytic properties should be conserved.

The promoter region of the pep operon shows several notable features (Fig. 1). Upstream of the divergent tacA transcription start site there is a binding site for the global transcription regulator CtrA (GAAA-N7-TTTAC; (21)) centered $25 \mathrm{bp}$ upstream of the $t a c A$ start site (14). The region upstream of orfl contains one inverted repeat that could have a regulatory role, centered at position -18 relative to orf 1 most upstream ATG. Two alternative start codons for orfl are located $15 \mathrm{bp}$ downstream, and at least the first of these has a good ribosome binding site consensus sequence.
A

Strains

$\beta$-gal activity

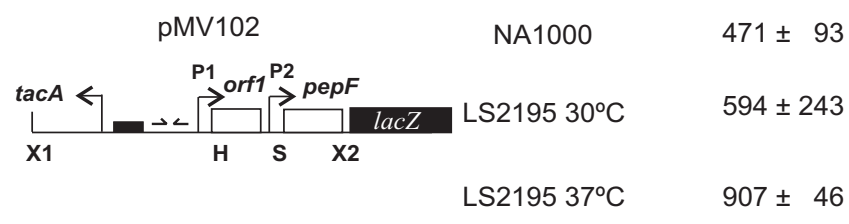

B

Plasmids $\quad \beta$-gal activity

pMV10

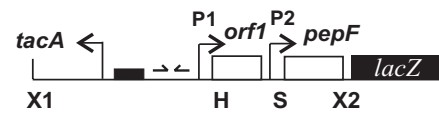

$471 \pm 93$

pMA13

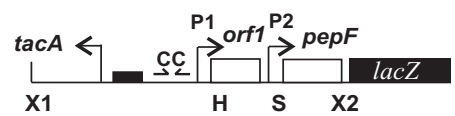

$694 \pm 107$

pVB04

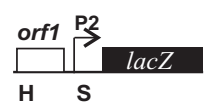

$333 \pm 83$

pVB01

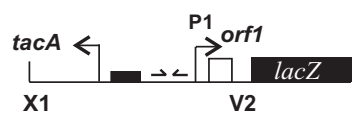

$113 \pm 37$

pVB07

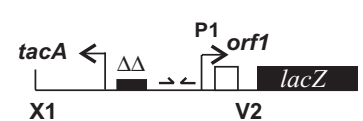

$134 \pm 73$

pMA03

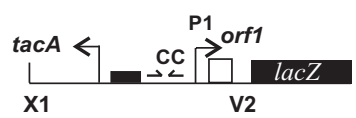

$88 \pm 25$

Figure 4. Determination of the transcriptional regulatory regions in the pepF locus. (A) Schematic representation of plasmid pMV102, which contains DNA from the beginning of the tacA gene (XhoI site) to the middle of the pepF gene cloned into the reporter vector pRKlacZ290. This plasmid was introduced into C. crescentus strains NA1000 and LS2195, and transcription levels were determined by b-galactosidase activity assays. (B) Different constructions of the pep regulatory region were cloned into pRKlacZ290 and these plasmids were introduced into $C$. crescentus NA1000 by conjugation. The transcriptional activity of each construction was determined by b-galactosidase activity assays. Numbers are the means of at least three independent measurements, followed by the respective standard deviation. Restriction sites are indicated as follows: $\mathrm{X}_{1}$ and $\mathrm{X}_{2}, \mathrm{XhoI}$; H, HindIII; S, StuI. $\mathrm{V} 2$, oligonucleotide used to generate the cloned fragment. Shaded box indicates the CtrA-binding site. Inverted arrows indicate the inverted repeat. White boxes indicate the open reading frames. $\triangle$ indicates deletion of two nucleotides in the pVB07 mutant. CC indicates substitution of two nucleotides in the pMA13 mutant. 
The expression of pep in two C. crescentus strains was determined through b-galactosidase activity assays in cells containing the pMV102 construction (Fig. 4A). This plasmid was introduced into strain NA1000 (wild type) and into strain LS2195, in which the CtrA protein is inactive at the temperature of $37^{\circ} \mathrm{C}$. In order to investigate whether $p e p F$ transcription was somehow affected by CtrA, its expression was determined by b-galactosidase activity assay both at $30^{\circ} \mathrm{C}$ and at $37^{\circ} \mathrm{C}$. Figure 4A shows that the levels of b-galactosidase activity were even a little higher at $37^{\circ} \mathrm{C}$, indicating that pepF expression is not affected by the absence of CtrA.

The RT-PCR results have indicated that two distinct promoters could be used to transcribe the $p e p F$ gene, one before orf1 (P1) and another between orf1 and pepF (P2). A two-base alteration in the inverted repeat localized at position -18 (from orfl first ATG) did not alter the levels of expression, indicating that this sequence does not have a regulatory role. In order to analyze each promoter separately, deletions were made both upstream and downstream the orfl gene (Fig. 4B). A deletion of the region upstream the HindIII site (pVB04) caused a little pronounced reduction in the b-galactosidase levels, suggesting that the promoter $\mathrm{P} 2$ between orf 1 and pepF is responsible for most the transcription activity. This can be also confirmed by deletion of downstream sequences, indicating that the P1 promoter is not very strong; the construction that removes the region downstream the beginning of orfl confers less than half the activity of b-galactosidase (compare pVB01 and pMV102). A mutation that inactivates the CtrA binding site has no effect in $\mathrm{P} 1$ activity (pVB07), but the two-base alteration in the inverted repeat causes a reduction in expression (pMA03). The results with pVB04 indicate that the region comprised between the HindIII site and the $S t u$ I site contains promoter activity, which is probably responsible for transcription of the pepF/orf 3 genes, explaining the increased amount of mRNA corresponding to pepF and orf3 observed in the RT-PCR.

The structure of the pep operon in $C$. crescentus is very interesting, since the $p e p F$ gene is co-transcribed with a gene encoding a putative protein kinase, which could indicate a coordinate role for the two peptides in the cell. The absence of cell cycle regulation indicates that this endopeptidase is probably involved in basal metabolic functions, as described for L. lactis $(16,17)$. However, we could see no gene induction by the presence of peptides in the culture medium, and the pepF mutant strain is able to grow using peptides as the sole carbon source (not shown), suggesting that there could be other peptidases in the cell which are responsible for nutrition.

\section{ACKNOWLEDGEMENTS}

The authors wish to thank Dr. Suely L. Gomes for her help throughout this work and for the critical reading of the manuscript and Dr. A.C.M. Camargo and people from his lab for their help with the endopeptidase assays. This work was supported by Fundação de Amparo à Pesquisa do Estado de São Paulo (FAPESP). During the course of this work, V.S.B. was supported by fellowships from FAPESP and from Conselho Nacional de Desenvolvimento Científico e Tecnológico (CNPq).

\section{RESUMO}

\section{Clonagem e caracterização do gene que codifica a endopeptidase PepF da bactéria aquática Caulobacter crescentus}

As metalopeptidases têm papel importante em bactérias, estando envolvidas em vários processos que dependem de reciclagem de proteínas, como nutrição, degradação de peptídios-sinal, localização de proteínas e virulência. Nós clonamos e caracterizamos o gene da metaloendopeptidase PepF da bactéria aquática Caulobacter crescentus. O gene a montante de pepF (orfl) codifica uma proteína hipotética conservada encontrada em Mycobacterium e Streptomyces. pepF é cotranscrito com o gene a juzante (orf3), que codifica uma proteína pertencente à família $\mathrm{ABC} 1$ de proteínas quinases, sugerindo que estas duas proteínas podem compartilhar uma função comum na célula. A proteína PepF de $C$. crescentus possui o motivo HEXGH presente nos domínios de ligação de zinco de homólogos de PepF. A interrupção do gene $p e p F$ por inserção de sequência de DNA de um vetor não gerou nenhum defeito de crescimento, mas a linhagem mutante possui apenas $30 \%$ da atividade especifica de endopeptidases presentes na linhagem selvagem. Deleções e mutações pontuais na região regulatória mostraram que há duas possíveis regiões promotoras, e a expressão do operon é independente do regulador de transcrição CtrA. Os resultados indicam que PepF não é essencial para o crescimento desta bactéria utilizando peptídios como fonte de carbono, sugerindo que outras peptidases possam estar realizando esta função.

Palavras-chave: endopeptidase, família M3, regulação gênica, bactéria

\section{REFERENCES}

1. Borodovsky, M.; McIninch, J. Recognition of genes in DNA sequence with ambiguities. Biosystems, 30: 161-171, 1993.

2. Brasseur, G.; Tron, G.; Dujardin, G.; Slonimski, P.P.; BrivetChevillote, P. The nuclear ABC1 gene is essential for the correct conformation and functioning of the cytochrome bc1 complex and the neighbouring complexes II and IV in the mitochondrial respiratory chain. Eur. J. Biochem., 246: 103-111, 1997.

3. Brun, Y.V.; Marczynski, G.; Shapiro, L. The expression of asymmetry during Caulobacter cell differentiation. Annu. Rev. Biochem., 63: 419-450, 1994

4. Camargo A.C.; Gomes M.D.; Reichl A.P.; Ferro E.S.; Jacchieri S.; Hirata I.Y.; Juliano L. Structural features that make oligopeptides susceptible substrates for hydrolysis by recombinant thimet oligopeptidase. Biochem. J., 324: 517-522, 1997. 
5. Chen, W.P.; Kuo, T.T. A simple and rapid method for the preparation of gram-negative bacterial genomic DNA. Nucleic Acids Res., 21: 2260, 1993.

6. Ely, B. Genetics of Caulobacter crescentus. Methods Enzymol., 204: 372-384, 1991.

7. Evinger, M.; Agabian, N. Envelope-associated nucleoid from Caulobacter crescentus stalked and swarmer cells. J. Bacteriol., 132: 294-301, 1977.

8. Gober, J.W.; Shapiro, L. A developmentally regulated Caulobacter flagellar promoter is activated by 3 ' enhancer and IHF binding elements. Mol. Biol. Cell, 3: 913-926, 1992.

9. Gober, J.W.; Marques, M.V. Regulation of cellular differentiation in Caulobacter crescentus. Microbiol. Rev., 59: 31-47, 1995.

10. Jenal, U.; Fuchs, T. An essential protease involved in bacterial cellcycle control. EMBO J., 17: 5658-69, 1998.

11. Jongeneel, C.V.; Bouvier, J.; Bairoch, A. A unique signature identifies a family of zinc-dependent metallopeptidases. FEBS Lett., 242: 211 214,1989

12. Kunkel, T.A.; Bebenek, K.; McClary, J. Efficient site-directed mutagenesis using uracil-containing DNA. Methods Enzymol., 204: $125-139,1991$

13. Leonard, C.J.; Aravind, L.; Koonin, E.V. Novel families of putative protein kinases in bacteria and archaea: evolution of the "eukaryotic" protein kinase superfamily. Genome Res., 8: 1038-1047, 1998.

14. Marques, M.V.; Gomes, S.L.; Gober, J.W. A gene coding for a putative sigma 54 activator is developmentally regulated in Caulobacter crescentus. J. Bacteriol., 179: 5502-5510, 1997.

15. Miller, J.H. Experiments in molecular genetics. Cold Spring Harbor Laboratory Press, Cold Spring Harbor, New York pp. 352-355, 1972.

16. Monnet, V.; Nardi, M.; Chopin, A.; Chopin, M.-C.; Gripon, J.-C. Biochemical and genetic characterization of PepF, an oligopeptidase from Lactococcus lactis. J. Biol. Chem., 269: 32070-32076, 1994.
17. Nardi, M.; Renault, P.; Monnet, V. Duplication of the pepF gene and shuffling of DNA fragments on the lactose plasmid of Lactococcus lactis. J. Bacteriol., 179: 4164-4171, 1997.

18. Nicholas K.B.; Nicholas Jr., H.B.; Deerfield II, D.W. GeneDoc: Analysis and Visualization of Genetic Variation, EMBNEW. NEWS, 4: 14, 1997.

19. Nierman, W.C.; Feldblyum, T.V.; Laub, M.T.; Paulsen, I.T.; Nelson, K.E.; Eisen, J.; Heidelberg, J.F.; Alley, M.R.; Ohta, N.; Maddock, J.R.; Potocka, I.; Nelson, W.C.; Newton, A.; Stephens, C.; Phadke, N.D.; Ely, B.; DeBoy, R.T.; Dodson, R.J.; Durkin, A.S.; Gwinn, M.L.; Haft, D.H.; Kolonay, J.F.; Smit, J.; Craven, M.B.; Khouri, H.; Shetty, J.; Berry, K.; Utterback, T.; Tran, K.; Wolf, A.; Vamathevan, J.; Ermolaeva, M.; White, O.; Salzberg, S.L.; Venter, J.C.; Shapiro, L.; Fraser, C.M. Complete genome sequence of Caulobacter crescentus. Proc. Natl. Acad. Sci. USA, 98: 4136-41, 2001.

20. Portaro, F.C.V.; Gomes, M.D.; Cabrera, A.; Fernandes, B.L.; Silva, C.L.; Ferro, E.S.; Juliano, L.; Camargo, A.C.M. Thimet oligopeptidase and the stability of MHC class I epitopes in macrophage cytosol. Biochem Biophys Res Commun., 255: 596-601, 1999.

21. Quon, K.C.; Marczynski, G.; Shapiro, L. Cell cycle control by an essential bacterial two-component signal transduction protein. Cell, 84: 83-93, 1996.

22. Rawlings, N.D.; Barrett, A.J. Evolutionary families of metallopeptidases. Meth. Enzymol., 248: 183-228, 1995.

23. Simon, R.; Priefer, U.; Puhler, A. A broad host range mobilization system for in vivo genetic engineering: transposon mutagenesis in gram negative bacteria. Biotechnology, 1: 784-790, 1983.

24. Thompson, J.D.; Higgins, D.G.; Gibson, T.J. CLUSTAL W: improving the sensitivity of progressive multiple sequence alignment through sequence weighting, positions-specific gap penalties and weight matrix choice. Nucleic Acids Res., 22: 4673-4680, 1994.

25. Wright, R.; Stephens, C.; Zweiger, G.; Shapiro, L.; Alley, M.R. Caulobacter Lon protease has a critical role in cell-cycle control of DNA methylation. Genes Dev., 10: 1532-42, 1996. 